\title{
FAKTOR-FAKTOR YANG MEMEPENGARUHI KEPATUHAN WAJIB PAJAK DALAM MEMBAYAR PAJAK PADA UMKM DI KOTA METRO.
}

\author{
Oleh: \\ Nedi Hendri \\ Email: nedi_hendri@yahoo.com \\ Fakultas Ekonomi, Universitas Muhammadiyah Metro
}

\begin{abstract}
The Compliance of SME in paying taxes will give a good impact in the creation of new tax sources which is will increase state revenues. However, if the factors affecting SMEs Actors Compliance is negative, then the Taxpayer Compliance will tend to rise and provide a good influence for the state revenue.

The purpose of this study was to determine the effect of the Knowledge Taxpayer, Taxation Sanction, Confidence, and awareness of the Taxpayer Compliance.

The research methods used in this research was the analysis of the path (path diagram). The result of the research shows that, the confidence level has no effect on tax compliance in paying taxes. While the knowledge of the taxpayer, tax penalties, and awareness of the taxpayers effect on tax compliance in paying taxes.
\end{abstract}

Keyword: Knowledge of Taxpayer, Taxation Sanction, Faith, Awareness Taxpayers and Taxpayer Compliance.

\section{LATAR BELAKANG}

Kepatuhan pajak merupakan persoalan yang sejak dulu ada di perpajakan. Di dalam negeri rasio kepatuhan wajib pajak dalam melaksanakan pemenuhan kewajiban perpajakannya dari tahun ke tahun masih menunjukkan persentase yang tidak mengalami peningkatan secara berarti. Hal ini didasarkan pada perbandingan jumlah wajib pajak yang memenuhi syarat patuh di Indonesia sedikit sekali jika dibandingkan dengan jumlah total wajib pajak terdaftar (Martowardojo, 2011).

Berdasarkan Undang- Undang Nomor 20 Tahun 2008 tentang Usaha Mikro, Kecil dan Menengah (UMKM) yang dimaksud dengan Usaha Kecil adalah usaha ekonomi produktif yang berdiri sendiri, yang dilakukan oleh orang perorangan atau badan usaha yang bukan merupakan anak perusahaan atau bukan cabang perusahaan yang dimiliki, dikuasai, atau menjadi bagian baik langsung maupun tidak langsung dari usaha menengah atau usaha besar yang memenuhi kriteria Usaha Kecil sebagaimana dimaksud dalam Undang-Undang ini dan Usaha 
Menengah adalah usaha ekonomi produktif yang berdiri sendiri, yang dilakukan oleh orang perseorangan atau badan usaha yang bukan merupakan anak perusahaan atau cabang perusahaan yang dimiliki, dikuasai, atau menjadi bagian baik langsung maupun tidak langsung dengan Usaha Kecil atau usaha besar dengan jumlah kekayaan bersih atau hasil penjualan tahunan sebagaimana diatur dalam Undang-Undang ini. Kriteria untuk usaha kecil yang dimaksud adalah apabila jumlah aset $>50$ juta -500 juta serta omzet $>300$ juta $-2,5$ miliar, dan untuk usaha menengah dimana jumlah aset $>500$ juta - 10 miliar serta omzet sebesar > 2,5 miliar - 50 miliar.

Fenomena yang terjadi saat ini adalah masih banyak wajib pajak yang belum memahami peraturan perpajakan. Sedangkan jumlah UKM yang banyak seharusnya berbanding lurus dengan jumlah pajak yang diterima dari sektor UKM. Faktanya, pajak dari sektor UKM hanya menyumbang 5\% total penerimaan pajak (Wisanggeni, 2012). UKM yang berjumlah 52,7 juta unit mempunyai potensi menjadi penyumbang pajak yang besar dalam pemasukan negara. Pemungutan pajak memang bukan suatu pekerjaan yang mudah, disamping peran serta aktif dari petugas perpajakan, juga dituntut kemauan dari para wajib pajak itu sendiri. Kepatuhan pelaku UMKM dalam membayar pajak khususnya di Kota Metro belum terlalu tinggi, Data Koperasi, UMKM, Dan Perindustrian Kota Metro tahun 2016 menunjukan dari 7.970 UMKM baru 6.866 yang telah memiliki NPWP. Sebagian pelaku UMKM belum melakukan pembukuan usahanya dan sebagian juga menganggap pajak sebagai beban karena pendapatan yang tidak tetap. Banyak pelaku UMKM yang kurang memiliki pemahaman mengenai peraturan perpajakan.

\section{RUMUSAN MASALAH}

Kepatuhan wajib pajak dipengaruhi oleh beberapa faktor, yaitu kesadaran wajib pajak, pengetahuan, sanksi perpajakan, dan tingkat kepercayaan wajib pajak. Penelitian ini akan mengkaji lebih lanjut menegenai faktor-faktor tersebut terutama pada kepatuhan wajib pajak dalam membayar pajak. Berdasarkan latar belakang masalah diatas, maka permasalahan yang akan diteliti dalam penelitian ini adalah: (1) Apakah Pengetahuan Wajib Pajak berpengaruh terhadap Kesadaran Wajib Pajak?, (2) Apakah Sanksi Perpajakan berpengaruh terhadap Kesadaran Wajib Pajak?, (3) Apakah Tingkat Kepercayaan Wajib Pajak berpengaruh terhadap Kesadaran Wajib Pajak?, (4)Apakah Tingkat Kepercayaan Wajib Pajak berpengaruh terhadap Kesadaran Wajib Pajak?, (5)Apakah Pengetahuan Wajib Pajak berpengaruh terhadap Kepatuhan Wajib Pajak?, (6)Apakah Sanksi Perpajakan berpengaruh terhadap Kepatuhan Wajib Pajak ?, (7)Apakah Tingkat Kepercayaan Wajib Pajak berpengaruh terhadap Kepatuhan Wajib Pajak?, dan (8)Apakah Kesadaran Wajib Pajak berpengaruh terhadap Kepatuhan Wajib Pajak?.

\section{KEPATUHAN WAJIB PAJAK}

Kepatuhan wajib pajak merupakan rasa bersalah dan rasa malu, persepsi wajib pajak atas kewajaran dan keadilan beban pajak yang mereka tanggung, dan pengaruh kepuasan terhadap pelayanan pemerintah. Menurut Mardiasmo (2009), 
Kepatuhan Wajib Pajak adalah suatu iklim kepatuhan dan kesadaran pemenuhan kewajiban perpajakan, tercermin dalam situasi di mana: (1)Wajib pajak paham atau berusaha untuk memahami semua ketentuan peraturan perundang-undangan perpajakan, (2)Mengisi formulir pajak dengan lengkap dan jelas, (3)Menghitung jumlah pajak yang terutang dengan benar, (4)Membayar pajak yang terutang tepat pada waktunya.

Keputusan Menteri Keuangan nomor : 544/KMK.04/2000, Wajib Pajak Patuh adalah Wajib Pajak yang memenuhi kriteria sebagai berikut:

1. Tepat waktu dalam menyampaikan Surat Pemberitahuan (SPT).

2. Tidak mempunyai tunggakan pajak untuk semua jenis pajak, kecuali tunggakan pajak yang telah memperoleh izin mengangsur atau menunda pembayaran pajak.

3. Laporan Keuangan diaudit oleh Akuntan Publik atau Lembaga Pengawasan Keuangan Pemerintah dengan pendapat wajar tanpa pengecualian selama 3 tahun berturut-turut

4. Tidak pernah dipidana karena melakukan tindak pidana di bidang perpajakan berdasarkan putusan pengadilan yang telah mempunyai kekuatan hukum tetap dalam jangka waktu 5 (lima) tahun terakhir.

Dari beberapa pendapat di atas dapat disintesiskan bahwa kepatuhan wajib pajak merupakan suatu keadaan dimana wajib pajak memiliki kesediaan untuk memenuhi kewajiban perpajakannya dengan tepat waktu dalam pembayarannya, tidak memiliki tungggakan, tidak pernah dipidana, dan mengisi SPT dengan jujur dan lengkap.

\section{PENGETAHUAN WAJIB PAJAK}

Pengetahuan adalah suatu proses atau cara dimana manusia mengerti, paham, dan mengetahui sesuatu yang bertujuan. Pengetahuan tentang peraturan perpajakan adalah cara wajib pajak dalam memahami peraturan perpajakan yang telah ada (Handayani, 2012). Sedangkan menurut Notoatmodjo (2007), pengetahuan adalah merupakan hasil dari tahu dan ini setelah orang melakukan penginderaan terhadap obyek tertentu. Penginderaan terjadi melalui panca indera manusia, yakni indera penglihatan, pendengaran, penciuman, rasa dan raba. Sebagian besar pengetahuan manusia diperoleh melalui mata dan telinga. Dari beberapa pendapat diatas dapat disintesiskan bahwa pengetahuan perpajakan merupakan hal yang paling mendasar yang harus dimiliki oleh wajib pajak agar wajib pajak dapat mengetahui tentang perpajakan, manfaat pajak, peraturan perpajakan, dan tata cara pemungutan pajak.

\section{SANKSI PERPAJAKAN}

Sanksi muncul dikarenakan suatu tindakan berupa hukuman yang diberikan kepada orang yang melanggar peraturan. Peraturan atau undang-undang merupakan rambu-rambu bagi seseorang untuk melakukan sesuatu mengenai apa yang harus dilakukan dan apa yang seharusnya tidak dilakukan. Sanksi diperlukan agar peraturan atau undang-undang tidak dilanggar. Sanksi pajak merupakan jaminan bahwa ketentuan dari peraturan perundang-undangan perpajakan (norma perpajakan) akan dituruti/ditaati/dipatuhi, dengan kata lain sanksi perpajakan 
merupakan alat pencegah agar wajib pajak tidak melanggar norma perpajakan (Mardiasmo,2009). Pandangan tentang sanksi perpajakan tersebut diukur dengan indikator sebagai berikut : (a) Sanksi pidana yang dikenakan bagi pelanggar aturan pajak cukup berat.(b)Sanksi adminstrasi yang dikenakan bagi pelanggar aturan pajak sangat ringan.(c)Pengenaan sanksi yang cukup berat merupakan salah satu sarana mendidik wajib pajak.(d)Sanksi pajak harus dikenakan kepada pelanggarnya tanpa toleransi, dan (e)Pengenaan sanksi atas pelanggaran pajak dapat dinegosiasikan.

\section{TINGKAT KEPERCAYAAN WAJIB PAJAK}

Menurut Mardiasmo (2009) kepercayaan merupakan suatu proses menghitung (calculative process) antara biaya yang dikeluarkan dengan hasil yang diperoleh. Kepercayaan sistem pemerintahan dan hukum dapat diartikan sebagai suatu bentuk penilaian antar lembaga negara dalam menyelenggarakan kekuasaan negara untuk kepentingan negara itu sendiri dalam rangka untuk mewujudkan kesejahteraan rakyat sesuai dengan undang-undang yang berlaku.

\section{KESADARAN WAJIB PAJAK}

Menurut Kamus Umum Bahasa Indonesia, kesadaran adalah keadaan tahu, mengerti, dan merasa. Kesadaran untuk mematuhi ketentuan (hukum pajak) yang berlaku tentu menyangkut factor-faktor apakah ketentuan tersebut telah diketahui, diakui, dihargai, dan ditaati. Kesadaran wajib pajak adalah suatu kondisi dimana wajib pajak mengetahui, memahami dan melaksanakan ketentuan perpajakan dengan benar dan sukarela. Irianto (2005) menguraikan beberapa bentuk kesadaran membayar pajak yang mendorong wajib pajak untuk membayar pajak. Terdapat tiga bentuk kesadaran utama terkait pembayaran pajak. Pertama, kesadaran bahwa pajak merupakan bentuk partisipasi dalam menunjang pembangunan negara. Dengan menyadari hal ini, wajib pajak mau membayar pajak karena merasa tidak dirugikan dari pemungutan pajak yang dilakukan. Pajak disadari digunakan untuk pembangunan negara guna meningkatkan kesejahteraan warga negara. Kedua, kesadaran bahwa penundaan pembayaran pajak dan pengurangan beban pajak sangat merugikan negara. Wajib pajak mau membayar pajak karena memahami bahwa penundaan pembayaran pajak dan pengurangan beban pajak berdampak pada kurangnya sumber daya finansial yang dapat mengakibatkan terhambatnya pembangunan negara. Ketiga, kesadaran bahwa pajak ditetapkan dengan undang-undang dan dapat dipaksakan. Wajib pajak akan membayar karena pembayaran pajak disadari memiliki landasan hukum yang kuat dan merupakan kewajiban mutlak setiap warga negara. Dari beberapa pengertian diatas maka dapat disintesiskan kesadaran wajib pajak adalah suatu kondisi dimana wajib pajak mengetahui fungsi pajak, mengakui kewajiban pajak, menghargai pemungut pajak dan mentaati ketentuan perpajakan. 


\section{KERANGKA PEMIKIRAN DAN HIPOTESIS PENELITIAN}

Berdasarkan rumusan dan kajian diatas diperoleh kerangka pemikiran dan hipotesis penelitian sebagai berikut:

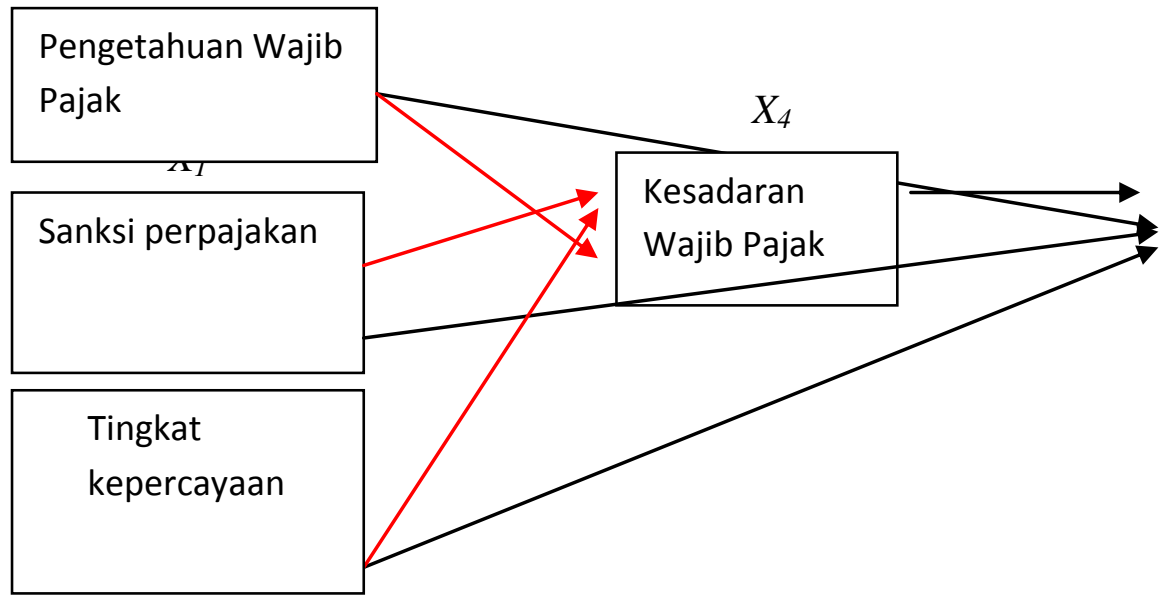

$X_{5}$

Gambar 1. Kerangka Pemikiran

Sedangkan Hipotesis statistik dalam penelitian ini adalah sebagai berikut:

1. $\mathrm{H}_{0}: \beta x_{4} \mathrm{x}_{1} \leq 0$ Pengetahuan Wajib Pajak $\left(\mathrm{X}_{1}\right)$ tidak berpengaruh terhadap

Kesadaran Wajib Pajak $\left(\mathrm{X}_{4}\right)$

$\mathrm{H}_{1}: \beta x_{4} \mathrm{x}_{1}>0$ Pengetahuan Wajib Pajak $\left(\mathrm{X}_{1}\right)$ berpengaruh terhadap Kesadaran Wajib Pajak $\left(\mathrm{X}_{4}\right)$

2. $\mathrm{H}_{0}: \beta x_{4} \mathrm{x}_{2} \leq 0$ Sanksi Perpajakan $\left(\mathrm{X}_{2}\right)$ tidak berpengaruh terhadap Kesadaran Wajib Pajak $\left(\mathrm{X}_{4}\right)$

$\mathrm{H}_{1}: \beta x_{4} \mathrm{X}_{2}>0$ Sanksi Perpajakan $\left(\mathrm{X}_{2}\right)$ berpengaruh terhadap Kesadaran Wajib Pajak $\left(\mathrm{X}_{4}\right)$

3. $\mathrm{H}_{0}: \beta x_{4} \mathrm{X}_{3} \leq 0$ Tingkat Kepercayaan Wajib Pajak $\left(\mathrm{X}_{3}\right)$ tidak berpengaruh terhadap Kesadaran Wajib Pajak $\left(\mathrm{X}_{4}\right)$

$\mathrm{H}_{1}: \beta x_{4} \mathrm{X}_{3}>0$ Tingkat Kepercayaan Wajib Pajak $\left(\mathrm{X}_{3}\right)$ berpengaruh terhadap Kesadaran Wajib Pajak $\left(\mathrm{X}_{4}\right)$

4. $\mathrm{H}_{0}: \beta x_{5} \mathrm{x}_{1} \leq 0$ Pengetahuan Wajib Pajak $\left(\mathrm{X}_{1}\right)$ tidak berpengaruh terhadap Kepatuhan Wajib Pajak $\left(\mathrm{X}_{5}\right)$

$\mathrm{H}_{1}: \beta x_{5} \mathrm{x}_{1}>0$ Pengetahuan Wajib Pajak $\left(\mathrm{X}_{1}\right)$ berpengaruh terhadap Kepatuhan Wajib Pajak $\left(\mathrm{X}_{5}\right)$

5. $\mathrm{H}_{0}: \beta x_{5} \mathrm{x}_{2} \leq 0$ Sanksi Perpajakan $\left(\mathrm{X}_{2}\right)$ tidak berpengaruh terhadap Kepatuhan Wajib Pajak $\left(\mathrm{X}_{5}\right)$

$\mathrm{H}_{1}: \beta x_{5} \mathrm{x}_{2}>0$ Sanksi Perpajakan $\left(\mathrm{X}_{2}\right)$ berpengaruh terhadap Kepatuhan Wajib Pajak $\left(\mathrm{X}_{5}\right)$

6. $\mathrm{H}_{0}: \beta x_{5} \mathrm{x}_{3} \leq 0$ Tingkat Kepercayaan Wajib Pajak $\left(\mathrm{X}_{3}\right)$ tidak berpengaruh terhadap Kesadaran Wajib Pajak $\left(\mathrm{X}_{4}\right)$

$\mathrm{H}_{1}: \beta x_{5} \mathrm{x}_{3}>0$ Tingkat Kepercayaan Wajib Pajak $\left(\mathrm{X}_{3}\right)$ berpengaruh terhadap Kepatuhan Wajib Pajak $\left(\mathrm{X}_{5}\right)$

7. $\mathrm{H}_{0}: \beta x_{5} \mathrm{x}_{4} \leq 0$ Kesadaran Wajib $\operatorname{Pajak}\left(\mathrm{X}_{4}\right)$ tidak berpengaruh terhadap Kepatuhan Wajib Pajak $\left(\mathrm{X}_{5}\right)$ 
$\mathrm{H}_{1}: \beta x_{5} \mathrm{X}_{4}>0$ Kesadaran Wajib Pajak $\left(\mathrm{X}_{4}\right)$ berpengaruh terhadap Kepatuhan Wajib Pajak $\left(\mathrm{X}_{5}\right)$

Model persamaan struktural untuk koefisien jalur diatas adalah sebagai berikut:

1. Sub Struktur 1

$\mathrm{X}_{4}=\beta \mathrm{X}_{4} \mathrm{X}_{1}+\beta \mathrm{X}_{4} \mathrm{X}_{2}+\beta \mathrm{X}_{4} \mathrm{X}_{3}+\mathrm{e}$

2. $\quad$ Sub Struktur 2

$\mathrm{X}_{5}=\beta \mathrm{X}_{5} \mathrm{X}_{1}+\beta \mathrm{X}_{5} \mathrm{X}_{2}+\beta \mathrm{X}_{5} \mathrm{X}_{3}+\beta \mathrm{X}_{5} \mathrm{X}_{4}+\mathrm{e}$

Keterangan:

$\boldsymbol{\beta}$

$\mathbf{X}_{1}$

$\mathbf{X}_{2}$

$\mathbf{X}_{3}$

$\mathbf{X}_{4}$

$\mathbf{X}_{5}$

e
: Koefisien Regresi

: Pengetahuan Wajib Pajak

: Sanksi Perpajakan

: Tingkat Kepercayaan Wajib Pajak

: Kesadaran Wajib Pajak

: Kepatuhan Wajib Pajak

: Error

\section{METODE PENELITIAN DAN ANALISIS DATA}

Jenis penelitian yang dilakukan oleh peneliti adalah penelitian verikatif dengan metode penelitian explanatory survey, yaitu suatu penelitian yang bertujuan untuk menguji hipotesis, yang umumnya merupakan penelitian yang menjelaskan fenomena dalam bentuk hubungan antara variabel. Dengan variabel exogennya: Pengetahuan Wajib Pajak, Efektivitas Sistem Perpajakan dan Tingkat Kepercayaan Wajib Pajak, sedangkan variabel endogennya adalah Kesadaran Wajib Pajak dan Kepatuhan Wajib Pajak yang diukur dengan menggunakan instrumen berupa kuesioner yang akan diberikan kepada wajib pajak dan diukur dengan menggunakan skala Likert.

Penelitian ini dilakukan pada wajib pajak pelaku UMKM yang ada di Kota Metro. Pengumpulan data dilaksanakan melalui penyebaran kuesioner secara langsung yang peneliti lakukan pada 14 Maret 2016 sampai 17 Maret 2016. Kuesioner yang disebarkan berjumlah 97 buah dan jumlah kuesioner yang dikembalikan berjumlah 78 kuesioner atau 80\%.kuesioner yang tidak kembali adalah 19 kuesioner atau 20\%. Kuesioner yang dapat diolah adalah 70 buah atau $89 \%$, sedangkan kuesioner yang tidak dapat diolah karena tidak diisi secara lengkap oleh responden adalah 8 buah atau $11 \%$.

Teknik analisis data yang digunakan dalam penelitian ini yaitu menggunakan:

a. Uji Prasyaratan Materi, menggunakan uji validitas dan uji reliabilitas.

Pengujian validitas dengan metode Pearson Correlation dimana suatu instrumen dikatakan valid atau tidak adalah jika korelasi antara skor masingmasing butir pertanyaan dengan total skor memiliki tingkat signifikansi dibawah 0,05sedangkan uji validitas menggunakan Cronbach Alpha diatas 0,60 . 
b. Uji Normalitas, untuk mengetahui apakah variabel dependent, idependent atau keduanya berdistribusi normal, atau mendekati normal. Model regresi yang baik hendaknya berdistribusi normal.

c. Uji Linearitas dan Keberartian Regresi, adalah salah satu persyaratan analisis bagi penggunaan statistik parametrik. Selain untuk memastikan bahwa sebaran data memiliki distribusi normal, homogen, uji peryaratn analisis ini bertujuan untuk memastikan bahwa persamaan regresi berbentuk linier dan signifikan.

d. Uji Analisis Jalur, menggunakan analisis jalur (Path Analysis). Bertujuan mengukur keterikatan antara Variable Independent, Variable Intermediate, dan Variable Dependent yang biasanya disajikan dalam bentuk diagram. Didalam diagram ada panah-panah yang menunjukkan arah pengaruh antara variabel-variabel exogenous, intermediate, dan variabel endogenous. Uji ini menggunakan program liserel.

\section{HASIL PENELITIAN}

a. Hasil Uji Validitas dan Reliabitas Data.

Berdasarkan tabel diatas, menunjukkan bahwa semua pertanyaan yang diajukan pada responden pelaku UKM telah mempunyai kriteria valid dengan korelasi 0,235 untuk semua item pertanyaan, kecuali item pertanyaan ke 7 untuk variabel $\mathrm{X}_{1}$ dan ke 12 untuk variabel $\mathrm{X}_{3}$. Dengan demikian, dapat dinyatakan bahwa seluruh item pertanyaan yang digunakan tersebut telah menunjukkan tingkat ketepatan yang cukup baik dan dapat digunakan untuk mengukur sesuatu yang diukur pada angket atau kuesioner.

Berikut ini adalah tabel hasil uji reliabilitas faktor-faktor yang mempengaruhi kepatuhan wajib pajak dalam membayar pajak yang terdiri dari variabel: Pengetahuan Wajib Pajak, Sanksi Perpajakan, Tingkat Kepercayaan, dan Kesadaran Wajib Pajak.

\section{Tabel 1}

\begin{tabular}{lcc}
\multicolumn{2}{c}{ Hasil Uji Reliabilitas Variabel } \\
Variabel & $\begin{array}{c}\text { Cronbach's } \\
\text { Alpha }\end{array}$ & Keterangan \\
Pengetahuan wajib pajak & .842 & Reliabel \\
Sanksi pajak & .898 & Reliabel \\
Tingkat kepercayan & .628 & Reliabel \\
Kesadaran wajib pajak & .659 & Reliabel \\
Kepatuhan wajib pajak & .666 & Reliabel \\
Sumber: Data primer yang diolah, 2016 & \\
Berdasarkan tabel diatas dapat disimpulkan bahwa \\
kuesioner dapat dikatakan reliabel karena mempunyai nilai Cronbach's Alpha
\end{tabular}


diatas 0,60. Hal ini berarti bahwa pertanyaan yang digunakan dapat memperoleh data yang konsisten dan apabila pertanyaan ini diajukan kembali akan memperoleh jawaban yang sama kembali.

b. Uji Normalitas.

Berikut ini adalah gambar yang menunjukkan hasil uji normalitas:

\section{Gambar 2}

\section{Hasil Uji Normalitas Menggunakan Grafik P-Plot}

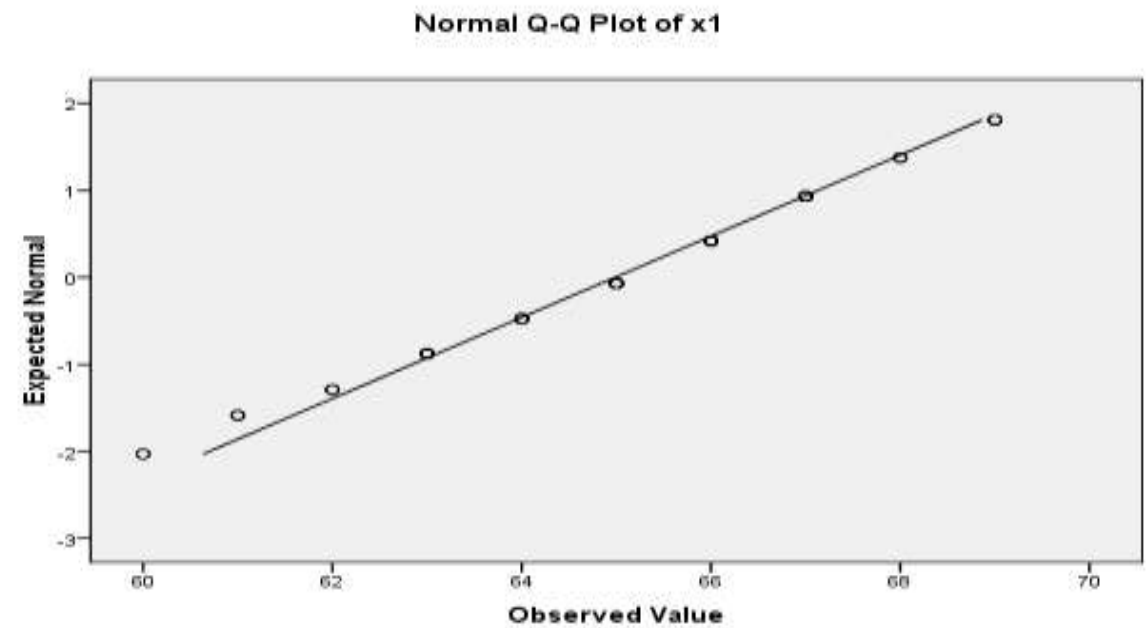

Sumber : Data primer yang diolah, 2016

Berdasarkan gambar diatas menunjukkan bahwa model regresi telah memenuhi asumsi normalitas yaitu memperlihatkan penyebaran data yang berada disekitar garis diagonal dan mengikuti arah garis diagonal.

c. Hasil Uji Linearitas dan Keberartian Regresi.

Berikut ini adalah tabel hasil uji linearitas sebagai berikut:

Tabel 3

Hasil uji linearitas ANOVA Table

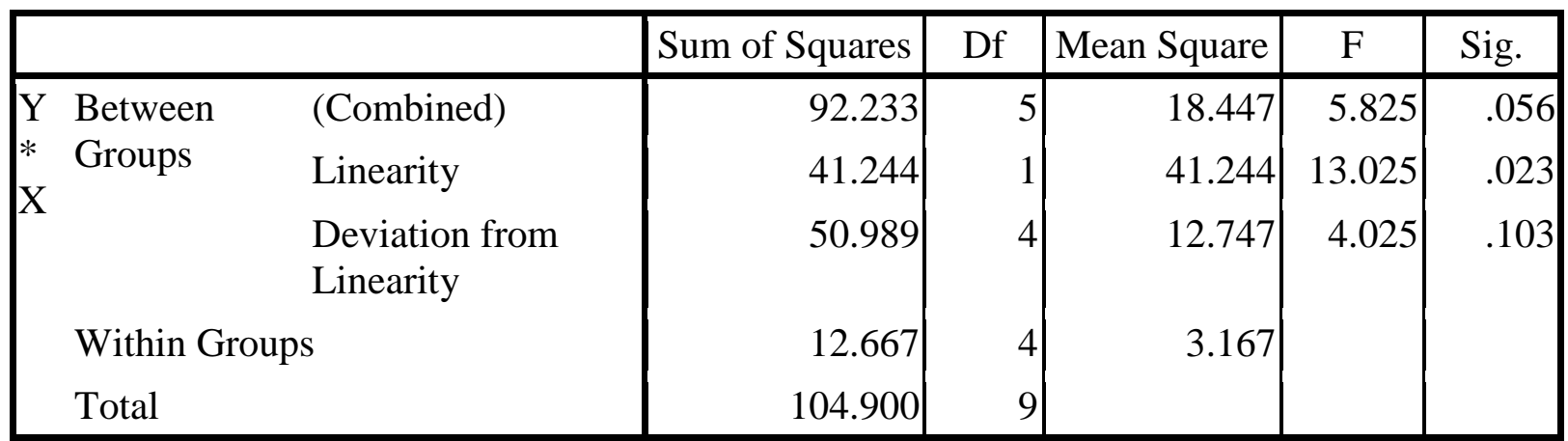

Sumber: Data primer yang diolah, 2016 
Bila taraf signifikan yang digunakan adalah 5\%, maka berdasarkan hasil output di atas, dapat disimpulkan bahwa data yang digunakan dapat dijelaskan oleh regresi linier dengan cukup baik karena nilai sig. Linearity sebesar 0,017 (lebih kecil dari 0,05) dan Sig. Deviation from Linearity sebesar 0,201 (lebih besar dari 0,05).

d. Hasil Uji Analisis Jalur (Part Analysis).

Berdasarkan pengujian hipotesis koefisien jalur setelah dilakukan trimming pada sub-struktur 1 dan sub-struktur 2 (berdasarhan tabel 4,5 dan 6 dibawah ini), keduanya membuktikan bahwa variabel yang digunakan dalam penelitian ini yaitu $\mathrm{X}_{4}$ terhadap $\mathrm{X}_{1}, \mathrm{X}_{5}$ terhadap $\mathrm{X}_{1}, \mathrm{X}_{5}$ terhadap $\mathrm{X}_{2}$, dan $\mathrm{X}_{5}$ terhadap $\mathrm{X}_{4}$ signifikan.

Tabel 4

Coefficients ${ }^{\mathrm{a}}$ Model 1 Sub-Struktur1

Coefficients $^{\mathbf{a}}$

\begin{tabular}{|c|c|c|c|c|c|c|}
\hline \multirow{2}{*}{\multicolumn{2}{|c|}{ Model }} & \multicolumn{2}{|c|}{$\begin{array}{c}\text { Unstandardized } \\
\text { Coefficients }\end{array}$} & \multirow{2}{*}{$\begin{array}{c}\text { Standardized } \\
\text { Coefficients }\end{array}$} & \multirow[b]{2}{*}{$\mathrm{t}$} & \multirow[b]{2}{*}{ Sig. } \\
\hline & & $\mathrm{B}$ & Std. Error & & & \\
\hline \multirow[t]{4}{*}{1} & (Constant) &,- 582 & 3,705 & &,- 157 & ,876 \\
\hline & pengetahuan & ,633 &, 175 &, 580 & 3,608 &, 001 \\
\hline & Sanksi & ,252 &, 130 & ,236 & 1,941 & ,057 \\
\hline & kepercayaan & , 119 & 108 &, 122 & 1,103 & ,274 \\
\hline
\end{tabular}

a. Dependent Variable: kesadaran

Tabel 5

Coefficients Model 2 Sub-Struktur 1

Coefficients $^{\mathrm{a}}$

\begin{tabular}{|c|c|c|c|c|c|}
\hline \multirow[t]{2}{*}{ Model } & \multicolumn{2}{|c|}{$\begin{array}{l}\text { Unstandardized } \\
\text { Coefficients }\end{array}$} & $\begin{array}{l}\text { Standardized } \\
\text { Coefficients }\end{array}$ & & \\
\hline & $\mathrm{B}$ & Std. Error & Beta & $\mathrm{t}$ & Sig. \\
\hline $\begin{array}{ll}1 & \text { (Constant) } \\
& \text { pengetahuan }\end{array}$ & $\begin{array}{r}68.760 \\
, 620\end{array}$ & $\begin{array}{r}12.083 \\
, 186\end{array}$ & 905, & $\begin{array}{r}5.691 \\
.333\end{array}$ & $\begin{array}{l}, 000 \\
, 001\end{array}$ \\
\hline
\end{tabular}

a. Dependent Variable: kesadaran

Tabel 6

Coefficients $^{\text {a }}$ Model 1 Sub-Struktur 2

Coefficients $^{\mathrm{a}}$

\begin{tabular}{|c|c|c|c|c|c|c|}
\hline \multirow{2}{*}{\multicolumn{2}{|c|}{ Model }} & \multicolumn{2}{|c|}{$\begin{array}{c}\text { Unstandardized } \\
\text { Coefficients }\end{array}$} & \multirow{2}{*}{$\begin{array}{c}\text { Standardized } \\
\text { Coefficients } \\
\text { Beta }\end{array}$} & \multirow[b]{2}{*}{$\mathrm{t}$} & \multirow[b]{2}{*}{ Sig. } \\
\hline & & $\mathrm{B}$ & Std. Error & & & \\
\hline \multirow[t]{3}{*}{1} & (Constant) & 6,919 & 5,140 & & 1,346 &, 183 \\
\hline & pengetahuan &, 500 & ,266 & ,455 & 1,880 & ,006 \\
\hline & Sanksi &, 044 & , 185 & ,040 & ,235 & ,015 \\
\hline
\end{tabular}




\begin{tabular}{|l|r|r|r|r|r|}
\hline kepercayaan &, 190 &, 151 &, 193 & 1,260 &, 012 \\
Kesadaran &, 244 &, 171 &, 242 & 1,432 &, 007 \\
\hline
\end{tabular}

a. Dependent Variable: kepatuhan

Hasil perhitungan sub struktur koefisien jalur adalah sebagai berikut:

$$
\begin{aligned}
& \text { Sub Struktur } 1= \\
& \qquad \begin{aligned}
\mathrm{R}_{\mathrm{X}_{3} \mathrm{X}_{1} \mathrm{X}_{2}}^{2} & =0,571 \\
\rho_{\mathrm{X}_{4} \in} & =\sqrt{1-\mathrm{R}_{\mathrm{X}_{3} \mathrm{X}_{1} \mathrm{X}_{2}}^{2}} \\
& =\sqrt{1-0,023}=\sqrt{0,977}=0,988
\end{aligned}
\end{aligned}
$$

$$
\begin{aligned}
& \text { Sub Struktur } 2 \begin{aligned}
= & \beta \mathrm{X}_{5} \mathrm{X}_{1}+\beta \mathrm{X}_{5} \mathrm{X}_{2}+\beta \mathrm{X}_{5} \mathrm{X}_{4}+\mathrm{e}_{3} \\
& =0,455 \mathrm{X}_{1}+0,240 \mathrm{X}_{2}+0,242 \mathrm{X}_{4}+0,571 \mathrm{e}_{3} \\
\mathrm{R}_{\mathrm{X}_{4} \mathrm{X}_{1} \mathrm{X}_{2} \mathrm{X}_{3}}^{2} & =0,867 \\
\rho_{\mathrm{X}_{5} \in} & =\sqrt{1-\mathrm{R}_{\mathrm{X}_{4} \mathrm{X}_{1} \mathrm{X}_{2} \mathrm{X}_{3}}^{2}} \\
& =\sqrt{1-0,674}=\sqrt{0,326}=0,571
\end{aligned}
\end{aligned}
$$

Apabila digambarkan studi kausal empirik tersebut adalah sebagai berikut: $\mathrm{X}_{1}$ , $\mathrm{X}_{2}, \mathrm{X}_{2}$ terhadap $\mathrm{X}_{4}$ dapat dibuat persamaan structural sebagai berkut:

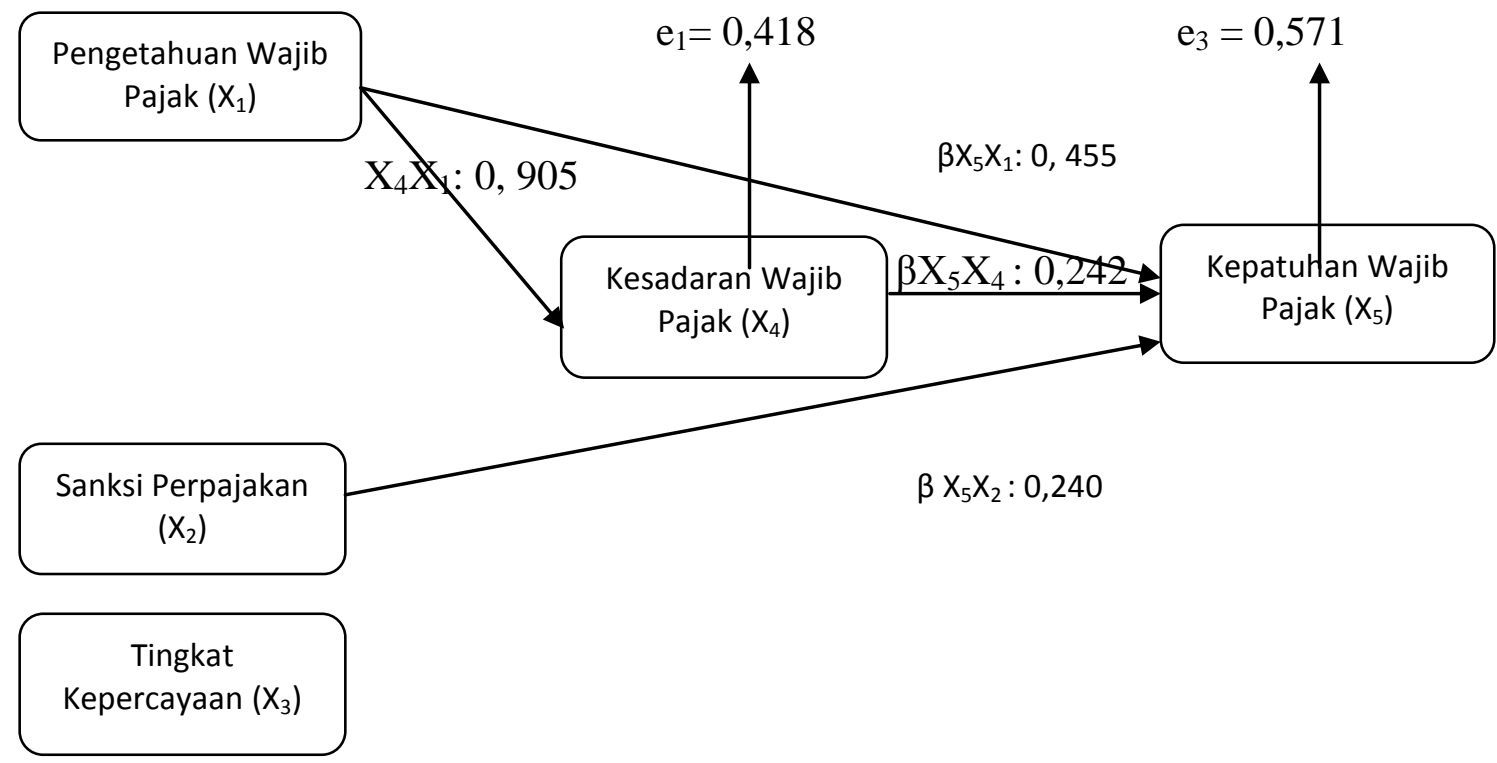

Gambar 2.

Model Kausal Sub-Struktur 1 Dan Sub-Struktur 2 
Selanjutnya pada tabel 7 dibawah ini menunjukan hasil perhitungan kooefisien jalurnya:

Tabel 7

koefisien jalur variabel $X_{1}, X_{2}, X_{3}, X_{4} X_{5}$

\begin{tabular}{|c|c|c|c|}
\hline Variabel & Pengaruh Langsung & Tidak Langsung Melalui & Total \\
\hline $\mathrm{X}_{4} \rightarrow \mathrm{X}_{1}$ & - & 0,905 & 0,905 \\
\hline $\mathrm{X}_{4} \rightarrow \mathrm{X}_{2}$ & - & - & - \\
\hline $\mathrm{X}_{4} \rightarrow \mathrm{X}_{3}$ & - & - & - \\
\hline $\mathrm{X}_{5} \rightarrow \mathrm{X}_{1}:$ & 0,455 & - & 0,455 \\
\hline $\mathrm{X}_{5} \rightarrow \mathrm{X}_{2}$ & 0,240 & - & 0,240 \\
\hline $\mathrm{X}_{5} \rightarrow \mathrm{X}_{3}$ & - & - & - \\
\hline $\mathrm{X}_{5} \rightarrow \mathrm{X}_{4}$ & 0,242 & - & 0,242 \\
\hline
\end{tabular}

Sumber: Data primer yang diolah, 2016

\section{PEMBAHASAN}

\section{Pengetahuan Wajib Pajak berpengaruh terhadap Kesadaran Wajib} Pajak

Hasil uji analisis jalur berdasarkan tabel 4, menunjukkan bahwa nilai Coefficient Beta untuk pengetahuan wajib pajak terhadap kesadaran wajib pajak yaitu sebesar 0,905 dengan tingkat signifikans 0,001 kurang dari 0,05. Sehingga pengetahuan berpengaruh terhadap kepatuhan wajib pajak.

Menurut Handayani (2012), pengetahuan adalah suatu proses atau cara dimana manusia mengerti, paham, dan mengetahui sesuatu yang bertujuan. Pengetahuan dapat meningkatkan kesadaran, semakin tinggi pengetahuan yang dimiliki oleh wajib pajak maka wajib pajak akan lebih terbuka dengan peraturan perpajakan yang diterapkan. Berdasarkan hasil penelitian yang dilakukan di Kota Metro, meskipun pelaku UKM telah terbiasa berinteraksi dengan petugas pajak, namun pelaku UKM masih banyak yang belum sukarela untuk membayar pajak karena menganggap pajak sebagai beban.

\section{Sanksi perpajakan tidak berpengaruh terhadap kesadaran wajib pajak}

Hasil uji analisis jalur berdasarkan tabel 4, menunjukkan bahwa nilai Coefficient Beta untuk sanksi perpajakan terhadap kesadaran wajib pajak yaitu sebesar 0,236 dengan tingkat signifikan 0,057 lebih besar dari 0,05. Sehingga sanksi perpajakan tidak berpengaruh terhadap kesadaran wajib pajak. Berdasarkan hasil penelitian yang dilakukan di Kota Metro, pelaku UKM masih menganggap pajak sebagai beban meskipun sudah ada sanksi 
yang akan diberikan apabila melanggar peraturan yang ditetapkan, tetapi masih banyak pelaku UKM yang belum menyadari dan menghindari pajak.

\section{Tingkat kepercayaan tidak berpengaruh terhadap kesadaran wajib pajak}

Hasil uji analisis jalur berdasarkan tabel 4, menunjukkan bahwa nilai Coefficient Beta untuk tingkat kepercayaan terhadap kesadaran wajib pajak yaitu sebesar 0,122 dengan tingkat signifikan 0,274 lebih besar dari 0,05. Sehingga tingkat kepercayaan tidak berpengaruh terhadap kesadaran wajib pajak.

Kepercayaan sistem pemerintahan dan hukum dapat diartikan sebagai suatu bentuk penilaian antar lembaga negara dalam menyelenggarakan kekuasaan negara untuk kepentinggan negara itu sendiri. Tingkat kepercayaan terhadap sistem pemerintahan dan hukum yang berlaku turut mendorong wajib pajak untuk membayar pajaknya. Dari hasil penelitian yang dilakukan di Kota Metro, kepercayaan pelaku UKM terhadap sistem pemerintahan dan hukum sebenarnya sudah baik namun, pelaku UKM tersebut masih enggan untuk membayarkan iuran pajaknya.

\section{Pengetahuan wajib pajak berpengaruh terhadap kepatuhan wajib pajak}

Hasil uji analisis jalur berdasarkan tabel 6, menunjukkan bahwa nilai Coefficient Beta untuk pengetahuan wajib pajak terhadap kepatuhan wajib pajak yaitu sebesar 0,455 dengan tingkat signifikan 0,006 lebih besar dari 0,05 . Sehingga pengetahuan wajib pajak berpengaruh terhadap kepatuhan wajib pajak.

Pengetahuan wajib pajak adalah informasi yang dimiliki oleh wajib pajak tentang peraturan perpajakan sehingga wajib pajak dapat melaksanakan kewajiban perpajakannya dengan baik. Dari hasil penelitian yang dilakukan di Kota Metro, sebagian pelaku UKM telah memiliki pengetahuan mengenai perpajakan. Akan tetapi masih banyak pula yang belum mau membayar iuran pajak tersebut.

\section{Sanksi perpajakan berpengaruh terhadap kepatuhan wajib pajak}

Hasil uji analisis jalur berdasarkan tabel 6, menunjukkan bahwa nilai Coefficient Beta untuk sanksi perpajakan terhadap kepatuhan wajib pajak yaitu sebesar 0,240 dengan tingkat signifikan 0,015 kurang dari 0,05. Sehingga sanksi perpajakan berpengaruh terhadap kepatuhan wajib pajak.

Sanksi pajak diberikan karena terjadi pelanggaran terhadap peraturan perpajakan, maka wajib pajak tersebut dihukum sesuai dengan indikasi kebijakan perpajakan dan perundang-undangan. Dengan adanya sanksi tersebut diharapkan tidak ada lagi pelanggaran dibidang perpajakan. Dari hasil penelitian yang dilakukan di Kota Metro, kepatuhan pelaku UKM sudah lebih baik dari tahun sebelumnya. Berarti bahwa pelaku UKM telah mematuhi peraturan perpajakan yang ditetapkan oleh Direktorat Jenderal Perpajakan. 


\section{Tingkat kepercayaan tidak berpengaruh terhadap kepatuhan wajib pajak}

Hasil uji analisis jalur berdasarkan tabel 6, menunjukkan bahwa nilai Coefficient Beta untuk tingkat kepercayaan terhadap kepatuhan wajib pajak yaitu sebesar 0,193 dengan tingkat signifikan 0,082 lebih dari 0,05. Sehingga tingkat kepercayaan tidak berpengaruh terhadap kepatuhan wajib pajak.

Kepercayaan yaitu kesediaan seseorang untuk menggantungkan dirinya pada pihak lain dengan resiko tertentu. Kepercayaan masyarakat terhadap sistem pemerintahan dan hukum dapat mendorong wajib pajak untuk membayar kewajibannya. Hasil penelitian yang dilakukan di Kota Metro menunjukkan kepercayaan para pelaku UKM sebenarnya sudah baik namun hal ini belum mampu untuk mendorong kepatuhan mereka untuk membayar pajak.

\section{Kesadaran wajib pajak berpengaruh terhadap kepatuhan wajib pajak}

Hasil uji analisis jalur berdasarkan tabel 6, menunjukkan bahwa nilai Coefficient Beta untuk kesadaran wajib pajak terhadap kepatuhan wajib pajak yaitu sebesar 0,242 dengan tingkat signifikan 0,007 kurang dari 0,05. Sehingga kesadaran wajib pajak berpengaruh terhadap kepatuhan wajib pajak.

Kepatuhan wajib pajak merupakan suatu keadaan dimana wajib pajak memiliki kesediaan untuk memenuhi kewajiban perpajakannya tanpa adanya pemaksaan atau pun sanksi yang diberikan, suka rela mau membayar pajak sesuai dengan peraturan yang berlaku. Dari hasil penelitian yang dilakukan di Kota Metro kesadaran wajib pajak dalam memenuhi kewajibannya sudah baik hal ini terbukti dengan tingkat kepatuhan wajib pajak yang tinggi dan berdampak baik pada penerimaan pajak penghasilan.

Berdasarkan hasil perhitungan sub struktur jalur secara keseluruhan, maka dapat dimaknai dan dibahas sehingga memberikan informasi secara obyektif sebagai berikut:

1. Jalur Sub-Struktur 1 menjelaskan "pengetahuan wajib pajak, sanksi perpajakan, dan tingkat kepercayaan berpengaruh terhadap kesadaran wajib pajak". Pengujian tersebut menjelaskan bahwa semakin tinggi pengetahuan wajib pajak, sanksi perpajakan, dan tingkat kepercayaan, maka kesadaran wajib pajak semakin meningkat. Pada kerangka yang telah berubah diatas menjelaskan bahwa pengetahuan wajib pajak memiliki hubungan langsung terhadap kesadaran wajib pajak. Berdasarkan pengujian secara individual, bahwa tidak semua variabel yang diterima, karena berdasarkan pengujian koefisien jalur substruktur 1, koefisien jalur sanksi perpajakan $\left(\mathrm{X}_{2}\right)$ dan tingkat kepercayaan $\left(\mathrm{X}_{3}\right)$ terhadap kesadaran wajib pajak $\left(\mathrm{X}_{4}\right)$ secara statistik tidak signifikan. Sedangkan koefisien pengetahuan wajib pajak $\left(\mathrm{X}_{1}\right)$ terhadap kesadaran wajib pajak $\left(\mathrm{X}_{4}\right)$ signifikan. Dengan demikian hasil temuan analisis ini memberikan informasi, bahwa pengetahuan wajib pajak berkontribusi terhadap kesadaran wajib pajak. Besarnya kontribusi pengetahuan wajib pajak terhadap kesadaran wajib pajak sebesar $0,905^{2} \times 100 \%=81,90 \%$ dan sisanya $0,9884^{2} \times 100 \%=97,69 \%$ merupakan kontribusi dari variabel lain diluar variabel pengetahuan wajib pajak. Kontribusi antara pengetahuan wajib pajak 
dan kesadaran wajib pajak berbanding lurus, dimana jika pengetahuan wajib pajak tinggi maka kesadaran wajib pajak akan baik. Hasil penelitian ini mendukung hipotesis yang pertama bahwa pengetahuan wajib pajak berpengaruh langsung positif terhadap kesadaran wajib pajak. Hal ini berarti kesadaran wajib pajak yang baik dapat dicapai jika pengetahuan wajib pajak yang dilmiliki oleh wajib pajak pajak tinggi. Hasil penelitian ini mendukung penelitian yang dilakukan oleh Widayati (2010) yang menyatakan bahwa pengetahuan wajib pajak berpengaruh terhadap kesadaran wajib pajak.

2. Jalur Sub-struktur 2 menjelaskan "pengetahuan wajib pajak, sanksi perpajakan, tingkat kepercayaan dan kesadaran wajib pajak berpengaruh terhadap kepatuhan wajib pajak". Pengujian tersebut menjelaskan bahwa, semakin tinggi pengetahuan wajib pajak, sanksi, tingkat kepercayaan, dan kesadaran wajib pajak, maka kepatuhan wajib pajak akan semakin meningkat. Pada kerangka hubungan yang telah berubah diatas menjelaskan bahwa pengetahuan wajib pajak memiliki hubungan langsung terhadap kepatuhan wajib pajak tanpa melalui kesadaran wajib pajak sebagai variabel intervening. Hal ini menjelaskan bahwa semakin tinggi pengetahuan wajib pajak maka akan semakin tinggi kepatuhan wajib pajak. Berdasarkan pengujian secara individual, bahwa semua variabel diterima, pengetahuan wajib pajak $\left(X_{1}\right)$, sanksi perpajakan $\left(\mathrm{X}_{2}\right)$, dan kesadaran wajib pajak $\left(\mathrm{X}_{4}\right)$ signifikan terhadap kepatuhan wajib pajak $\left(\mathrm{X}_{5}\right)$. Kecuali untuk variabel tingkat kepercayaan wajib pajak $\left(\mathrm{X}_{3}\right)$ tidak berpengaruh terhadap kepatuhan wajib pajak $\left(\mathrm{X}_{5}\right)$.

Hasil penelitian ini mendukung penelitian Widayati dan Nurlis (2010) yang membuktikan bahwa pengetahuan, sanksi perpajakan, dan kesadaran wajib pajak berpengaruh terhadap kepatuhan wajib pajak. Penelitian lain yang mendukung adalah penelitian yang dilakukan oleh Widarto (2013).

\section{SIMPULAN PENELITIAN}

Berdasarkan pada data yang dikumpulkan dan pengujian yang dilakukan, maka dapat diambil kesimpulan sebagai berikut:

a. Pengetahuan wajib pajak berpengaruh signifikan terhadap kesadaran wajib pajak.

b. Sanksi perpajakan tidak berpengaruh terhadap kesadaran wajib pajak.

c. Tingkat kepercayaan tidak berpengaruh terhadap kesadaran wajib pajak.

d. Pengetahuan wajib pajak berpengaruh langsung terhadap kepatuhan wajib pajak.

e. Sanksi perpajakan berpengaruh langsung terhadap kepatuhan wajib pajak.

f. Tingkat kepercayaan tidak berpengaruh langsung terhadap kepatuhan wajib pajak.

g. Kesadaran wajib pajak berpengaruh terhadap kepatuhan wajib pajak.

Sedangkan variabel yang paling dominan mempengaruhi kepatuhan pelaku UKM dalam membayar kewajiban pajaknya adalah pengetahuan, karena pelaku usaha akan membayar pajak apabila mereka mengetahui kegunaan pajak serta pajak yang telah dibayarkan dikelola dengan tertip, efisien, transparan, dan bertanggungjawab. 


\section{DAFTAR PUSTAKA}

Handayani, Septi Wuri dan Agus Faturrokhman, Umi Pratiwi. 2012. Faktor-faktor yang Mempengaruhi Kemauan Pajak Wajib Pajak Orang Pribadi yang Melakukan Pekerjaan Bebas. Makalah Simposium Nasional Akuntansi 15, Banjarmasin, 20-23 September 2012.

Irianto, Slamet Edi. 2005. Politik Perpajakan; Membangun Demokrasi Negara. Yogyakarta: UII pres.

Keputusan Menteri Keuangan Nomor 544/KMK.04/2000 tentang Kriteria Wajib Pajak yang dapat diberikan Pengembalian Pendahuluan Kelebihan Pajak.

Mardiasmo. 2009. Perpajakan Edisi Revisi 2009. Yogyakarta: Andi

Martowardojo. 2011. Baru 7 Persen Masyarakat yang Sadar Pajak.

Http://www.economy.okezone.com/read/2016/03/20/5089977/menkeu-

baru-7-masyarakat-yang-sadar-pajak. Diakses pada 30 Februari 2016.

Notoatmodjo, Soekidjo. 2007. Pengembangan Sumber Daya Manusia. Jakarta: PT. Rineka Cipta.

Undang-undang Nomor 20 Tahun 2008 tentang Usaha Mikro, Kecil dan Menengah.

Undang-undang Nomor 28 Tahun 2007 tentang Ketentuan Umum dan Tata Cara Perpajakan.

Widayawati dan Nurlis, 2010. Faktor-faktor yang Mempengaruhi Kemauan Membayar Pajak Wajib Pajak Orang Pribadi yang Melakukan Pekerjaan Bebas pada KPP Pratama Gambir Tiga. Makalah Simposium Nasional Akuntansi 13, Purwokerto.

Widarto, Edwin. 2013. Faktor-Faktor Yang Mempengaruhi Kemauan Untuk Membayar Pajak Pada Usaha Kecil Dan Menengah (UKM) Di Surabaya. Tesis. Fakultas Bisnis Universitas Katolik Widya Mandala.

Wisanggeni, Irawan. 2012. Pajak untuk UMK. Kompas, 1 Februari 2012. 